\title{
Bacterial Profile in Primary Teeth with Necrotic Pulp and Periapical Lesions
}

\author{
Léa Assed Bezerra da SILVA ${ }^{1}$ \\ Paulo NELSON-FILHO ${ }^{1}$ \\ Gisele FARIA $^{1}$ \\ Maria Cristina Monteiro de SOUZA-GUGELMIN ${ }^{2}$ \\ Izabel Yoko ITO ${ }^{2}$ \\ ${ }^{1}$ Department of Pediatric Clinics, Preventive and Social Dentistry, Faculty of Dentistry of Ribeirão Preto, \\ University of São Paulo, Ribeirão Preto, SP, Brazil \\ ${ }^{2}$ Department of Clinical Analysis, Toxicology and Bromatology, \\ Faculty of Pharmaceutical Sciences of Ribeirão Preto, University of São Paulo, Ribeirão Preto, SP, Brazil
}

\begin{abstract}
The objective of this study was to evaluate the bacterial profile in root canals of human primary teeth with necrotic pulp and periapical lesions using bacterial culture. A total of 20 primary teeth with necrotic pulp and radiographically visible radiolucent areas in the region of the bone furcation and/or the periapical region were selected. After crown access, 4 sterile absorbent paper points were introduced sequentially into the root canal for collection of material. After $30 \mathrm{~s}$, the paper points were removed and placed in a test tube containing reduced transport fluid (RTF) and were sent for microbiological evaluation. Anaerobic microorganisms were found in $100 \%$ of the samples, black-pigmented bacilli in 30\%, aerobic microorganisms in $60 \%$, streptococci in $85 \%$, Gram-negative aerobic rods in $15 \%$ and staphylococci were not quantified. Mutans streptococci were found in 6 root canals (30\%), 5 canals with Streptococcus mutans and 1 canal with Streptococcus mutans and Streptococcus sobrinus. It was concluded that in root canals of human primary teeth with necrotic pulp and periapical lesions, the infection is polymicrobial with predominance of anaerobic microorganisms.
\end{abstract}

Key Words: primary teeth, necrotic pulp, microorganisms.

\section{INTRODUCTION}

After determination of the important role of bacteria in the pathogenesis of pulp and periapical lesions $(1,2)$, elimination of infection from the root canal system became the objective of endodontic treatment of teeth with necrotic pulp and periapical lesions $(3,4)$.

Until 1970, the most common bacterial group isolated by culture from root canals of permanent teeth was viridans streptococci (alpha hemolytic streptococci) (5). Then, with the development of strictly anaerobic culture techniques, the concept of endodontic infection changed because anaerobic microorganisms, which had been rarely isolated, were seen as the predominant endodontic microbiota in permanent teeth with necrotic pulp and periapical lesions $(6,7)$.
However, there are few studies concerning root canal microbiota of primary teeth. Marsh and Largent (3) reported alpha hemolytic streptococci as the predominant microrganisms whereas other studies $(8,9)$ reported that the most prevalent microorganisms in root canals of primary teeth with necrotic pulp and periapical lesions were Streptococcus salivarius. Anaerobic microorganisms represented over $70 \%$ of the microbiota in root canals of primary molars that had been treated unsuccessfully (10) and were also the most prevalent bacteria in teeth indicated for extraction (11).

Endodontic treatment of primary teeth with necrotic pulp is routine in dental practice. Control of infection is fundamental because the ample medullary bone spaces favor dissemination of infection and also because the developing permanent tooth germ is very

Correspondence: Prof. Dr. Paulo Nelson-Filho, Departamento de Clínica Infantil, Odontologia Preventiva e Social, Faculdade de Odontologia de Ribeirão Preto, USP, Avenida do Café, S/N, 14040-904 Ribeirão Preto, SP, Brasil. Tel: +55-16-3602-4099. Fax: +55-163633-0999. e-mail: nelson@forp.usp.br 
close to the roots of the primary teeth. Thus, it is fundamental that the dentist be aware of the microbiota in these teeth so that adequate antimicrobial agents may be used to eliminate these pathogens.

The purpose of this study was to evaluate the prevalence of microorganisms in root canals of human primary teeth with necrotic pulp and periapical lesions, using the culture technique.

\section{MATERIAL AND METHODS}

The participants of this study were 20 patients (3-7 years old) of both sexes selected from patients treated at the Pediatric Clinic of the Faculty of Dentistry of Ribeirão Preto, USP (Brazil). They were in good general health and had not been treated with antibiotics for at least 3 months. This study was approved by the local Ethics in Research Committee.

Twenty primary teeth $(7$ maxillary incisors, 8 mandibular molars and 5 maxillary molars, providing a total of 20 root canals) with necrotic pulp and radiographically visible radiolucent areas in the region of the bone furcation and/or the periapical region were used. The teeth had carious lesions but the root canals were not exposed directly to the oral environment. The teeth had intact roots or less than $2 / 3$ of physiological root resorption, no periodontal pockets and no intervention of the root canals. The remaining crown allowed isolation with a rubber dam and further restoration.

Clinical Procedures. After antisepsis of the oral cavity by rinsing for $1 \mathrm{~min}$ with $10 \mathrm{~mL}$ of $0.12 \%$ digluconate chlorhexidine (Periogard; Colgate-Palmolive Ind. Brasileira, Osasco, SP, Brazil), local anesthesia was administered, a rubber dam was placed and the operative field was disinfected with $1 \%$ digluconate chlorhexidine. After removal of the carious tissue, the area was disinfected and root canal access was done with highspeed spherical diamond burs (KG Sorensen Indústria e Comércio, São Paulo, SP, Brazil) and Endo-Z files (Les Fills d'August, Maillefer, Ballaigues, Switzerland), cooled with air and water.

Bacteriological samples were collected just after crown access introducing 4 sequential sterile absorbent paper points of size compatible with root canal diameter up to the working length, which was delimited $2 \mathrm{~mm}$ from the radiographic apex or to the limit of the physiological root resorption. After $30 \mathrm{~s}$, the paper points were removed from the canals and placed in a test tube containing $2 \mathrm{~mL}$ of reduced transport fluid (RTF) prepared according to Syed and Loesche (12). For the maxillary molars, samples were collected from the palatal root canal and for the mandibular molars samples were collected from the distal root canal.

After sample collection, the root canals were treated for immediate and progressive neutralization of septic/toxic content using K-files and copious irrigation/ aspiration with $2.5 \%$ sodium hypochlorite followed by odontometry $1 \mathrm{~mm}$ from the radiographic apex or the limit of the physiological root resorption. Biomechanical preparation was carried out with sequential K-files and irrigation with $2.5 \%$ sodium hypochlorite. The canals were dried with sterile absorbent paper points and filled with EDTA (Odahcan Herpo Produtos Dentários Ltda., Rio de Janeiro, RJ, Brazil), which was stirred for $3 \mathrm{~min}$ with a K-file to remove smear layer. The canals were irrigated, dried and filled with a calcium hydroxidebased paste (Calen PMCC; S.S. White Artigos Dentários Ltda., Rio de Janeiro, RJ, Brazil) using a special syringe (ML; S.S. White Artigos Dentários Ltda.). The pulp chamber was sealed with zinc oxide and eugenol cement (IRM; Dentsply Indústria e Comércio Ltda., Petrópolis, RJ, Brazil). After 14-30 days, the intracanal dressings were removed and the canals were filled with Calen paste thickened with zinc oxide, as advised by the Department of Pediatric Clinics, Preventive and Social Dentistry of the Faculty of Dentistry of Ribeirão Preto, USP (Brazil) and restored.

Laboratory Procedures. At the Microbiology Laboratory of the Faculty of Pharmaceutical Sciences of Ribeirão Preto, USP (Brazil), 4-6 glass beads and sterile metal wings were added to the test tubes containing the samples. The tubes were agitated for $2 \mathrm{~min}$ in a mixer (Mixtron Leucoton Equipamentos Ltda, São Paulo, SP, Brazil) at maximum speed. Subsequently, serial decimal dilutions up to $10^{-5}$ were made in Sorensen phosphate buffer (PBS) under laminar airflow. A volume of 0.05 $\mathrm{mL}$ of the pure samples and of each dilution were seeded with a sterile calibrated pipette, onto plates containing blood agar(Ba; Difco, Detroit, MI, USA), Mitis Salivarius agar (Ms; Difco) and blood agar supplemented with 5.0 $\mu \mathrm{g} / \mathrm{mL}$ hemin and $1.0 \mu \mathrm{g} / \mathrm{mL}$ menadione (Bak; Sigma Chemical Co., St. Louis, MO, USA). Plates containing salt agar with hypertonic egg yolk agar (Ni), MacConkey agar (Mc; Difco) and bacitracin sucrose agar $\left(\mathrm{SB}_{20}\right)$ were seeded up to $10^{-1}$ dilutions. $\mathrm{SB}_{20}$ was prepared according to Davey and Rogers (13), modified by 
replacement of sacarose with cane sugar.

Bak plates were incubated anaerobically using the GasPak system for 7-10 days; Ms and $\mathrm{SB}_{20}$ plates were incubated microaerobically by the candle jar system for 2-3 days; and $\mathrm{Ba}, \mathrm{Mc}$ and $\mathrm{Ni}$ plates were incubated aerobically for $24-48 \mathrm{~h}$ at $37^{\circ} \mathrm{C}$. Colonies were the counted using a stereomicroscope (Nikon, Tokyo, Japan) with reflected light and expressed as cfu/mL.

From the $\mathrm{SB}_{20}$ agar plates, 3-4 colonies suspected of being $S$. mutans and $S$. sobrinus were isolated and identified according to Shklair and Keene (14), i.e., fermentation of mannitol, sorbitol, raffinose and melibiose, hydrolysis of arginine and sculin, production of $\mathrm{H}_{2} \mathrm{O}_{2}$ and sensitivity to $2.0 \mathrm{IU}$ bacitracin.

\section{RESULTS}

Anaerobic microorganisms were present in all 20 canals (100\%), varying from 140 to $13,300,000 \mathrm{cfu} / \mathrm{mL}$ (Table 1). Black-pigmented bacilli were found in 6 cases $(30 \%)$. Aerobic microorganisms were found in 12 root canals $(60 \%)$, ranging from 40 to $183,000 \mathrm{cfu} / \mathrm{mL}$. Streptococci were present in 17 root canals $(85 \%$; range: $20-192,000 \mathrm{cfu} / \mathrm{mL})$. Mutans streptococci were found in 6 canals $(30 \%$; range: $20-134,000 \mathrm{cfu} / \mathrm{mL})$, with Streptococcus mutans present in 5 canals and Streptococcus mutans and S. sobrinus in 1 canal. Aerobic Gram-negative rods were found in 3 root canals $(15 \%)$. No staphylococci were found.

\section{DISCUSSION}

In the present study, anaerobic and aerobic microorganisms, black-pigmented bacilli, streptococci, mutans streptococci and Gram-negative aerobic rods were found. This is in agreement with Toyoshima et al. (10) who reported that in root canals of primary teeth with necrotic pulp and periapical lesions submitted to retreatment there is a polymicrobial infection with predominance of anaerobic microorganisms, similar to the microbiota of permanent teeth.

Among the anaerobic microorganisms, black-

Table 1. Bacterial profile in root canals of primary teeth with necrotic pulp and periapical lesions.

\begin{tabular}{ccccccc}
\hline Case & Anaerobes & BPB & Aerobes & Streptococci & MS & GNAR \\
\hline 1 & $13,300,000$ & 71,000 & 0 & 0 & 0 & 0 \\
2 & $3,600,000$ & 315,000 & 0 & 0 & 0 & 0 \\
3 & $9,900,000$ & 440,000 & 40 & 0 & 0 & 0 \\
4 & $5,350,000$ & 10,200 & 0 & 1,130 & 0 & 0 \\
5 & $1,260,000$ & 0 & 7,000 & 23,000 & 40 & 0 \\
6 & $2,400,000$ & 0 & 183,000 & 192,000 & 0 & 0 \\
7 & $6,400,000$ & 0 & 72,000 & 120,000 & 0 & 40 \\
8 & 301,000 & 0 & 1,870 & 1,370 & 0 & 0 \\
9 & $3,230,000$ & 101,000 & 0 & 20 & 0 & 0 \\
10 & 710,000 & 49,000 & 0 & 370 & 0 & 0 \\
11 & 140 & 0 & 0 & 40 & 0 & 0 \\
12 & 4,000 & 0 & 0 & 120 & 0 & 0 \\
13 & 4,100 & 0 & 40 & 80 & 0 & 0 \\
14 & 3,800 & 0 & 0 & 2,400 & 20 & 0 \\
15 & 140 & 0 & 80 & 120 & 0 & 0 \\
16 & 580,000 & 0 & 38,000 & 149,000 & 134,000 & 0 \\
17 & 570,000 & 0 & 3,100 & 137,000 & 1,690 & 40 \\
18 & 2,800 & 0 & 200 & 2,500 & 660 & 40 \\
19 & 8,500 & 0 & 2,600 & 2,800 & 0 & 0 \\
20 & 720,000 & 0 & 2,600 & 2,200 & 140 & 0 \\
Total* & $20(100 \%)$ & $6(30 \%)$ & $12(60 \%)$ & $17(85 \%)$ & $6(30 \%)$ & $3(15 \%)$ \\
\hline
\end{tabular}

$\mathrm{BPB}=$ black-pigmented bacilli; MS = mutans streptococci; GNAR = Gram-negative aerobic rods. Total $*$ number of canals infected by each bacterial strain. 
pigmented bacilli have frequently been isolated from root canals of permanent teeth with necrotic pulp. Sundqvist et al. (15) reported their presence in 30\% of the cases while other authors using immunofluorescence $(7,16)$ found these microorganisms in $49 \%$ and $60 \%$ of the samples, respectively. In this study, blackpigmented bacilli were found in 6 cases (30\%), which is consistent with the findings of a previous investigation (9) that found $36 \%$. However, these results differ from those of Toyoshima et al. (10) who isolated blackpigmented bacilli in $44.4 \%$ of retreatment cases.

Aerobic microorganisms were found in only 12 root canals (60\%). Sato et al. (11) also reported a greater percentage of anaerobic than aerobic bacteria in primary teeth with necrotic pulp and periapical lesions indicated for extraction. Gram-negative aerobic rods, frequently found in periodontal pockets, were present in only 3 cases $(15 \%)$. These outcomes are in agreement with those of Cohen et al. (8), who found these pathogens in $17 \%$ of primary teeth with necrotic pulp.

Although other studies have reported the presence of staphylococci $(3,8,9)$, these microorganisms were not found in the present study. Reader et al. (17) believe that their presence may be due to contamination during endodontic treatment.

Streptococci were isolated in $85 \%$ of the cases, which is consistent with the findings of Marsh and Largent (3) (82\%). Mutans streptococci were found in 6 cases $(30 \%)$, with S. mutans and/or S. sobrinus present in some cases. Mutans streptococci have been isolated from root canals of permanent teeth in $52 \%$ of the cases (9). The methodology used in this study was the same as that used by Assed et al. (9), with the difference that in their study some of the root canals were exposed directly to the oral environment. However, there are no reports in the literature of the presence of mutans streptococci in root canals of primary teeth.

According to the results of this study, anaerobic bacteria, black-pigmented bacilli, aerobic bacteria, streptococci and mutans streptococci are components of root canal microbiota of primary teeth with necrotic pulp and periapical lesions. In summary, all root canals examined present a polymicrobial infection and the most prevalent microorganisms were anaerobic. This is in agreement with the findings of previous studies $(6,18)$, which found that $\mathrm{CO}_{2}$-dependent microaerobic streptococci and other aerobic and facultative microorganisms prepare the environment for the installation of anaerobes by consuming oxygen leading to the development of low redox potential. This gradual decrease in oxygen tension in root canals, together with the nutritional needs of microorganisms and the food chain, leads to the occurrence of natural selection (microbial shift) and predominance of anaerobic microorganisms in teeth with necrotic pulp and periapical lesions (6).

The success of endodontic treatment depends on several factors, the most important of which is the reduction or elimination of bacterial infection $(4,19)$. Because the microbiota of root canals of primary teeth with necrotic pulp and periapical lesions is similar to that found in permanent teeth, endodontic treatment should be similar. Pediatric dentistry should include the neutralization of necrotic content, instrumentation and intracanal dressings as essential steps of root canal therapy of these teeth.

Further research should be carried out to investigate root canal microbiota of primary teeth with necrotic pulp and periapical lesions before and after endodontic treatment.

\section{RESUMO}

O objetivo desse estudo foi avaliar, por meio de cultura bacteriológica, a prevalência de microrganismos em canais radiculares de dentes decíduos de humanos com necrose pulpar e lesão periapical. Foram selecionados 20 dentes decíduos humanos com necrose pulpar e lesão periapical. Após a realização da abertura coronária foi efetuada a colheita para exame bacteriológico do conteúdo do canal radicular, introduzindo-se seqüencialmente 4 cones de papel absorvente esterilizados, providos de aleta metálica, de número compatível com o diâmetro do canal radicular. Após $30 \mathrm{~s}$, os cones foram removidos e transferidos para um tubo de ensaio contendo fluido para transporte reduzido (RTF) e enviados para processamento microbiológico. Os microrganismos anaeróbios foram quantificados em $100 \%$ dos casos, os bacilos pigmentados de negro em $30 \%$, os aeróbios em $60 \%$, os estreptococos em $85 \%$, os bacilos gram-negativos aeróbios em $15 \%$ dos casos e os estafilococos não foram quantificados. Os estreptococos do grupo mutans foram quantificados em 6 canais radiculares $(30 \%)$, sendo que em 5 canais estavam presentes Streptococcus mutans e em 1 canal Streptococcus mutans e Streptococcus sobrinus. Concluiu-se que nos canais radiculares de dentes decíduos de humanos portadores de necrose pulpar e lesão periapical há uma infecção polimicrobiana com predomínio de microrganismos anaeróbios.

\section{REFERENCES}

1. Kakehashi S, Stanley HR, Fitzgerald RJ. The effects of surgical exposure of dental pulps in germ-free and conventional laboratory rats. Oral Surg Oral Med Oral Pathol 
1965;20:340-349.

2. Tani-Ishii N, Wang C-Y, Tanner A, Stashenko P. Changes in root canal microbiota during the development of rat periapical lesions. Oral Microbiol Immunol 1994;9:129-135.

3. Marsh SJ, Largent MD. A bacteriological study of the pulp canals of infected primary molars. J Dent Child 1967;34:460470 .

4. Leonardo MR, Rossi MA, Silva LAB, Ito IY, BonifacioKC. EM evaluation of bacterial biofilm and microorganisms on the apical external root surface of human teeth. J Endod 2002;28:815-818.

5. Morse DR. Endodontic microbiology in the 1970s. Int Endod J 1981;14:69-79.

6. Sundqvist G. Ecology of the root canal flora. J Endod 1992;18:427-430.

7. Assed S, Ito IY, Leonardo MR, Silva LAB, Lopatin DE. Anaerobic microorganisms in root canals of human teeth with chronic apical periodontitis detected by indirect immunofluorescence. Endod Dent Traumatol 1996;12:6668.

8. Cohen MM, Joress SM, Calisti LP, Mass B. Bacteriologic study of infected deciduous molars. Oral Surg Oral Med Oral Pathol 1960;3:1382-1386.

9. Tomic-Karovic K, Jelinek E. Comparative study of the bacterial flora in the surroundings, the root canals and sockets of deciduous molars. Int Dent J 1971;21:375-388.

10. Toyoshima Y, Fukushima H, Inoue JI, Sasaki Y, Yamamoto K, Katao H, Ozaki K, Moritani Y, Saito T, Hieda T, et al. A bacteriological study of periapical pathosis on deciduous teeth. JPN Dent J 1988;26:449-458.
11. Sato T, Hoshino E, Uematsu H, Noda T. Predominant obligate anaerobes in necrotic pulps of human deciduous teeth. Microb Ecol Health Dis 1993;6:269-275.

12. Syed AS, Loesche WJ. Survival of human dental plaque flora in various transport media. Appl Microbiol 1972;24:638644.

13. Davey AL, Rogers AH. Multiple types of bacterium Streptococcus mutans in the human mouth and their intra-family transmission. Arch Oral Biol 1984;29:453-460.

14. Shklair IL, Keene HJ. A biochemical scheme for the separation of five varieties of Streptococcus mutans. Arch Oral Biol 1974;19:79-81.

15. Sundqvist G, Johansson E, Sjögren U. Prevalence of blackpigmented bacteroides species in root canal infections. J Endod 1989;15:13-19.

16. Pantera Jr. EA, Zambon JJ, Shih-Levine M: Indirect immunofluorescence for detection of bacteroides species in human dental pulp. J Endod 1988;14:218-223.

17. Reader CM, Boniface M, Bujanda-Wagne S. Refractory endodontic lesion associated with Staphylococcus aureus. J Endod 1994;20:607-609.

18. Farber PA, Seltzer S. Endodontic microbiology I. Etiology. J Endod 1988;14:363-371.

19. Silva LA, Leonardo MR, Assed S, Tanomaru Filho M. Histological study of the effect of some irrigating solutions on bacterial endotoxin in dogs. Braz Dent J 2004;15:109-114.

Accepted April 3, 2006 